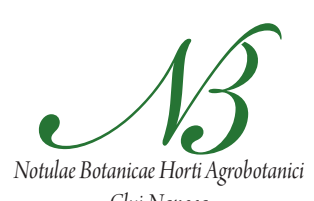

Cluj-Napoca

\title{
Nitrogen and Crude Proteins in Beetroot (Beta vulgaris var. conditiva) under Different Fertilization Treatments
}

\author{
Marko PETEK ${ }^{1}$, Mirjana HERAK ĆUSTIĆ ${ }^{1}$, Nina TOTH² ${ }^{2}$, Sanja SLUNJSKIㄹ ${ }^{1}$, Lepomir ČOGA ${ }^{1}$ \\ Ivan PAVLOVIĆ ${ }^{\prime}$, Tomislav KARAŽIJA ${ }^{1}$, Boris LAZAREVIĆ ${ }^{1}$, Saša CVETKOVIĆ ${ }^{3}$ \\ ${ }^{1}$ University of Zagreb, Faculty of Agriculture, Department of Plant Nutrition, Svetosimunska \\ 25, HR-10000 Zagreb,Croatia; mpetek@agr.hr ( ${ }^{*}$ corresponding author) \\ ${ }^{2}$ University of Zagreb, Faculty of Agriculture, Department of Vegetable Crops, Svetosimunska 25, HR-10000 Zagreb, Croatia \\ ${ }^{3}$ University of Zagreb, Faculty of Agriculture, Svetosimunska 25, HR-10000 Zagreb, Croatia
}

\begin{abstract}
The research aim was to determine the influence of different organic and mineral fertilization treatments and post-harvest treatments on the content of nitrogen and crude proteins in the edible part of beetroot (Beta vulgaris var. conditiva). A field trial (2003-2005) was set

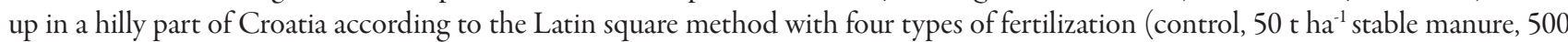
and $1000 \mathrm{~kg} \mathrm{ha}^{-1}$ NPK 5-20-30), while treatments involved harvested fresh beetroot and stored fresh beetroot. The highest dry weight (DW) content was determined in climatologically favourable 2004 (average 14.8\% DW) and in the treatment with $1000 \mathrm{~kg}$ ha ${ }^{-1} \mathrm{NPK}$ 5-20-30 (15.6\% DW) in harvested beetroot. In 2004 and 2005, the highest levels of nitrogen and crude proteins in harvested beetroot were determined in the treatment with $1000 \mathrm{~kg} \mathrm{ha}^{-1} \mathrm{NPK} 5-20-30$ (2.41 and $2.43 \mathrm{~g} \mathrm{~N} \mathrm{~kg}^{-1}$ in fresh weight and 15.07 and $15.21 \mathrm{~g}^{\mathrm{crude}}$ proteins $\mathrm{kg}^{-1}$ in fresh weight, respectively). Regardless of fertilization treatment or studied year, nitrogen and crude protein contents were higher in stored than in harvested beetroot, by $12 \%$ on average. The lowest crude protein content was determined in treatment with stable manure what confirmed that protein content decreased by organic fertilization. It can be concluded that beetroot lost some water during the storage period, which increased its content of nitrogen and crude proteins in fresh weight and thus increased the nutritional quality of beetroot as a functional food.
\end{abstract}

Keywords: Beta vulgaris var. conditiva, crude proteins, fertilization, nitrogen, storage

\section{Introduction}

Nutritional value of vegetables is not only in his energy content but also in present proteins and minerals (Ekholm et al., 2007, Lisiewska et al., 2006) that are basis for maintaining a healthy human organism in well condition (Gopalan and Tamber, 2003). Owning to high concentrations of minerals (Petek et al., 2008) and vitamins, beetroot has a special role in the human diet.

Nitrogen has a great importance as a constituent of numerous organic molecules in plant such as proteins, nucleic acids and alkaloids (Bergmann, 1992), and its content is associated with the leaf relative chlorophyll content (Horvat et al., 2011; Lazarević et al., 2011) which affects photosynthesis. Nitrogen is the plant nutrient that is often most limiting to efficient and profitable crop production. Inadequate supply of available $\mathrm{N}$ frequently results in plants that have slow growth, depressed protein levels, poor yield of low quality produce, and inefficient water use (Mikkelsen and Hartz, 2008).

Plants absorb nitrogen in the form of ions $\left(\mathrm{NH}_{4}{ }^{+} \mathrm{i}\right.$ $\mathrm{NO}_{3}^{-}$) through the roots or leaves and incorporate it in organic matter throughout the whole growing season by transforming the mineral into an organic form (Bergmann, 1992).

The vegetable yield does not increase continuously by increasing nitrogen fertilization. Excessive doses of nitrogen reduce the growth and yield (Wang and $\mathrm{Li}, 2003$ ). Wang et al. (2008) report that nitrogen fertilization increases the ratio of acids and sugars and reduces the content of vitamin C, calcium, magnesium and soluble sugars, while Feller and Fink (2004) report that nitrogen fertilization did not affect the content of soluble substances. Increased application of nitrogen reduced the content of dry matter, potassium, sucrose, vitamin $\mathrm{C}$ and fiber in leafy vegetables, but increased the content of nitrates and carotenes (Sorensen, 1999). Nitrogen is attributed to the role of one of the most important macronutrients in the formation of yield and quality of vegetables (Sorensen $e t$ al., 1995; Wang et al., 2008). However, nitrogen fertilization of vegetables aimed at increasing protein levels still attracts very little attention (Herak Ćustić et al., 2009). Lešić et al. (2002) state that beetroot contains 0.14 to $2.50 \% \mathrm{~N}$ in dry weight and Varo et al. (1980) report $3.3 \mathrm{~g} \mathrm{~N} \mathrm{~kg}^{-1}$ in fresh weight. 
216

Crude proteins have a considerable role in livestock (Grbeša, 2004) and human nutrition. However, grains, meat, milk and soybean are always cited as sources of crude proteins, mainly in cattle feeding (Grbeša, 2004; Veldkamp et al., 2008).

Rembiatkowska (2007) reports that quantity of crude proteins is lower in organic than in conventional crops. Mikkelsen and Hartz (2008) report that inadequate supply of available $\mathrm{N}$ frequently results depressed protein levels in plant, and generally, protein content increases with nitrogen uptake (Brandt and Molgaard, 2001). For protein levels, it has been reported that organically grown cereals, especially wheat, can have comparable protein levels with conventional ones but generally have somewhat lower levels of protein than the conventional ones (Lairon, 2009). However, in environments rich in readily assimilable nitrogen, i.e. conventional systems, the metabolism of plants changes in the direction of intensive production of nitrogen-containing compounds such as free amino acids, proteins and alkaloids (Hallmann and Rembiałkowska, 2012).

It is worth mentioning that vegetables are not a negligible source of crude proteins, especially given the fact that considerable amounts of vegetables should be consumed daily. In literature there are a very little data about crude proteins in beetroot. Herak Ćustić et al. (2009) report that red head chicory contains up to $259 \mathrm{~g} \mathrm{~kg}^{-1}$ crude proteins in dry weight. Lešić et al. (2002) state that beetroot, as a functional food, contains $11-20 \mathrm{~g} \mathrm{~kg}^{-1}$ crude proteins in fresh weight, root celery 7-20 g kg radishes 5 to $15.5 \mathrm{~g} \mathrm{~kg}^{-1}$. Wybenga and Lehr (1958) report the value of $131-214 \mathrm{~g} \mathrm{~kg}^{-1}$ crude proteins in beetroot dry weight and Varo et al. (1980) $20.63 \mathrm{~g} \mathrm{~kg}^{-1}$ crude proteins in fresh weight of beetroot.

Literature report following dry weight of beetroot: 14.7\% (Lisiewska et al., 2006) and 14.0-14.6\% (Wold et al., 2008).
The present research aim was to determine the influence of different organic and mineral fertilization treatments and post-harvest treatments on the content of nitrogen and crude proteins in the edible part of beetroot (Beta vulgaris var. conditiva).

\section{Materials and methods}

A field fertilization trial with beetroot (Beta vulgaris var. conditiva), cultivar 'Bikor', was laid out in Brašljevica and Hrvatsko Polje (Croatia) (Fig. 1) from 2003 to 2005 according to the Latin square method with four treatments (unfertilized control, $50 \mathrm{t} \mathrm{ha}^{-1}$ stable manure, and 500 and $1000 \mathrm{~kg} \mathrm{ha}^{-1}$ NPK 5-20-30).

Untreated beetroot seed was sown directly into soil and harvested only once after 90 days. Plant spacing was $0.07 \mathrm{~m}$ $\mathrm{x} 0.40 \mathrm{~m}$; the main plot area was $12 \mathrm{~m}^{2}$. Average mass of 1 beetroot in 2003, 2004 and 2005 was 121, 230 and $200 \mathrm{~g}$, respectively. Beetroot was stored 45 days at $5^{\circ} \mathrm{C}$ in a fridge without light. Dry homogenized samples of plant material $\left(105^{\circ} \mathrm{C}\right)$ were analyzed in triplicate and the results are presented as mean values. Nitrogen was determined by the Kjeldahl method (AOAC, 1995). Crude proteins were calculated according to the following formula: $\% \mathrm{~N} \mathrm{x} 6.25$ (Vajić, 1964). Investigations were performed on soil with soil reaction $(\mathrm{pH})$ of 6.1-6.6, with low to moderate humus and nitrogen content, poor in phosphorus and low to rich potassium content (Tab. 1).

The closest meteorological station for Brašljevica is Jastrebarsko and for Hrvatsko Polje is Otočac. The total precipitation throughout the year 2003 (Dia. 1a) were 766 $\mathrm{mm}$, which is less than a multi annual average $(935 \mathrm{~mm}$, Tab. 2). Mean daily air temperature during the period of beetroot growing were $19-23^{\circ} \mathrm{C}$ and were higher for 2 to $4^{\circ} \mathrm{C}$ in comparison to multi annual average (Tab. 2). Year 2003 was relatively unfavourable for beetroot growing because of the lack of precipitation and poor ratio between

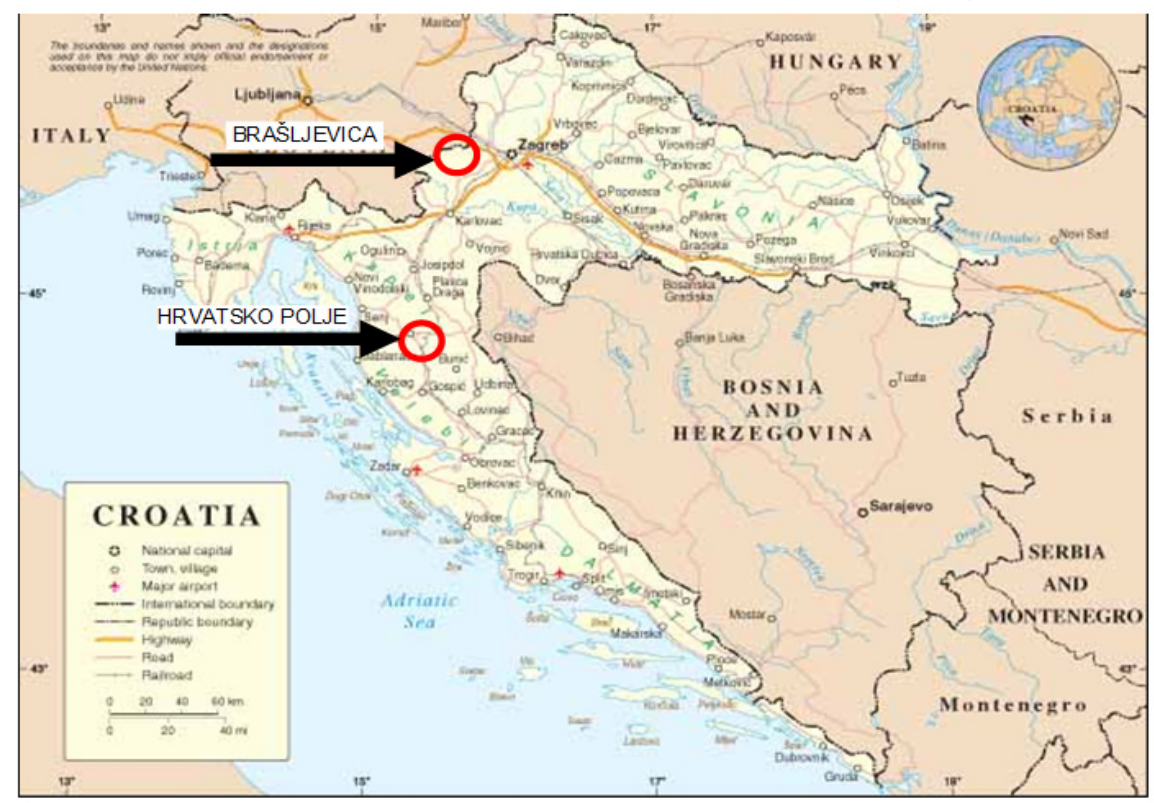

Fig. 1. Map of Croatia with highlighted locations of investigation (Brašljevica and Hrvastko Polje) 
Tab. 1. Chemical properties of investigated soils

\begin{tabular}{cccccc}
\hline \multirow{2}{*}{ Year, location } & \multirow{2}{*}{$\mathrm{pH}$} & \multicolumn{2}{c}{$\%$} & \multicolumn{3}{c}{$\mathrm{AL}-{\mathrm{mg} 100 \mathrm{~g}^{-1}}$} & humus & $\mathrm{N}$ & $\mathrm{P}_{2} \mathrm{O}_{5}$ & $\mathrm{~K}_{2} \mathrm{O}$ \\
\hline 2003, Brašljevica & 6,5 & 2,17 & 0,12 & 0,1 & 6,0 \\
2004, Hrvatsko Polje & 6,1 & 2,65 & 0,13 & 1,5 & 15,3 \\
2005, Hrvatsko Polje & 6,6 & 3,10 & 0,16 & 6,2 & 32,8 \\
\hline
\end{tabular}

temperature and precipitation. In year 2004 (Dia. 1b) weather conditions during the growing season was favourable for beetroot growing thanks to the reserves of soil water before the growing as well as to the rain during the first half of the growing period. Total precipitation during the year was $1238 \mathrm{~mm}$, which is $133 \mathrm{~mm}$ higher than the multi annual average (1105 mm, Tab. 2). Temperatures were lower than in 2003 and the ratio between temperature and precipitation was good and had favourable influence on the growth and development of beetroot. During the beetroot growing period of 2005 (July-September), total precipitation was $423 \mathrm{~mm}$ (Dia. 1c) and was higher for $198 \mathrm{~mm}$ than the multi annual average $(225 \mathrm{~mm}$, Tab. 2). Temperatures were favourable for the growth of beetroot. Generally, according to precipitation and tempera-

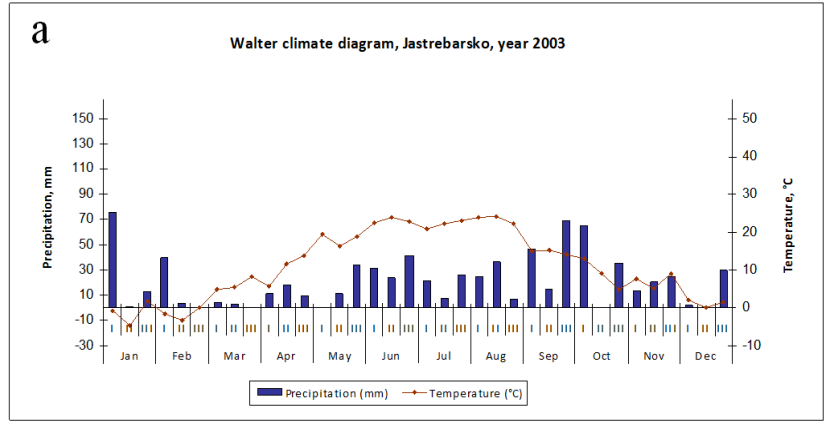

217

ture data for the growing period, the year 2003 was dry, 2004 was optimal and 2005 was humid.

Statistical data analyses were performed using the SAS 8.2 System (2002-2003).

\section{Results and discussion}

The highest dry weight (DW) content (Tab. 3) was determined in climatologically favourable $2004(14.8 \%$ DW on average) and in treatment with $1000 \mathrm{~kg} \mathrm{ha}^{-1} \mathrm{NPK}$ 5-20-30 (15.6\% DW) in harvested beetroot possibly due to the favorable ratio of temperature and precipitation, which is according to some authors considered as a favorable value (Lisiewska et al., 2006; Wold et al., 2008). In dry 2003 and humid 2005, dry weight was statistically significantly higher in stored than in harvested beetroot. Although Sorensen (1999) reported that increased nitrogen application reduces the dry matter content, in this study it was not found. In 2004 and 2005 the highest dry matter content $(15.6$, or $7.3 \%)$ was determined at fertilization with $1000 \mathrm{~kg}$ NPK ha ${ }^{-1}$, thus by increasing the nitrogen fertilization. Dry weight content by manure fertilization in all three years had the lowest value compared to other fertilizer treatments probably because of the small quanti-

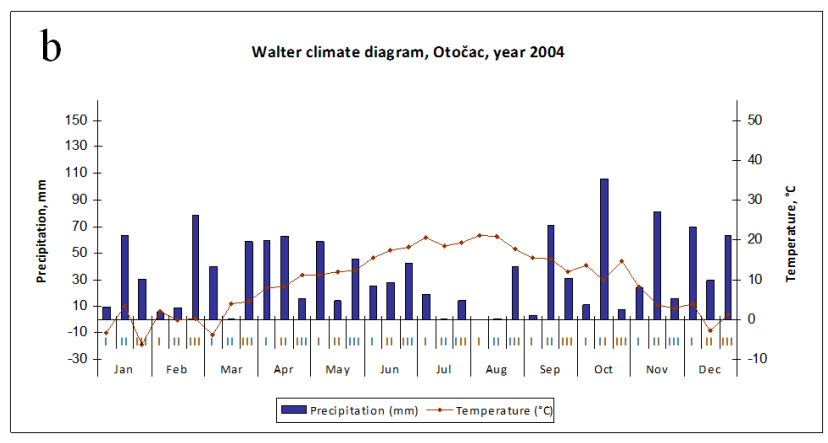

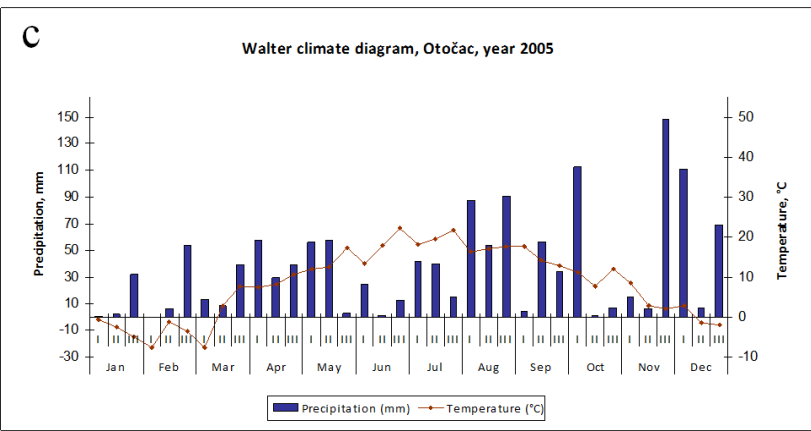

Dia. 1 ( $\mathrm{a}, \mathrm{b}$ and $\mathrm{c})$. Walter climate diagrams for meteorological stations Jastrebarsko and Otočac

Tab. 2. Multi annual (1961-1991) climate data for meteorological stations Jastrebarsko and Otočac

\begin{tabular}{|c|c|c|c|c|c|c|c|c|c|c|c|c|}
\hline Months & Jan & Feb & Mar & Apr & May & Jun & $\mathrm{Jul}$ & Aug & Sep & Oct & Nov & Dec \\
\hline \multicolumn{13}{|c|}{ Jastrebarsko } \\
\hline $\mathrm{TMP}^{*}$ & 54 & 51 & 60 & 70 & 74 & 100 & 78 & 87 & 105 & 92 & 88 & 76 \\
\hline $\mathrm{AMT}^{* *}$ & $-0,4$ & 1,1 & 5,9 & 10,6 & 15,6 & 18,7 & 20,7 & 20,2 & 15,6 & 10,8 & 4,9 & 0,9 \\
\hline \multicolumn{13}{|c|}{ Otočac } \\
\hline TMP* $^{*}$ & 79 & 68 & 75 & 89 & 86 & 77 & 47 & 81 & 127 & 113 & 137 & 127 \\
\hline $\mathrm{AMT}^{* *}$ & $-1,0$ & 0,1 & 3,9 & 8,9 & 14,1 & 17,8 & 19,7 & 19,0 & 13,9 & 10,5 & 5,0 & 0,1 \\
\hline
\end{tabular}

*TMP - total month precipitation $(\mathrm{mm}) ;{ }^{* *} \mathrm{AMT}$ - average month temperature $\left({ }^{\circ} \mathrm{C}\right)$ 
Tab. 3. Dry weight (in \%) in harvested and stored beetroot according to different fertilization treatments

\begin{tabular}{cccccccccc}
\hline & \multicolumn{9}{c}{ \% Dry Weight } \\
\cline { 2 - 11 } & \multicolumn{2}{c}{2003} & \multicolumn{2}{c}{2004} & \multicolumn{2}{c}{2005} & \multicolumn{3}{c}{ Average } \\
\hline Treatment & Harvested & Stored & Harvested & Stored & Harvested & Stored & Harvested & Stored \\
\hline Control & $7.1 \mathrm{a}^{* *}$ & 10.2 & 14.7 & 14.5 & 7.3 & 10.8 & 9.7 & 11.8 \\
Manure & $6.2 \mathrm{~b}$ & 11.2 & 13.9 & 13.5 & 6.3 & 9.9 & 8.8 & 11.6 \\
NPK500* & $6.7 \mathrm{ab}$ & 10.9 & 15.0 & 12.8 & 7.0 & 9.9 & 9.6 & 11.2 \\
NPK1000* & $6.9 \mathrm{ab}$ & 9.8 & 15.6 & 15.1 & 7.3 & 10.8 & 9.9 & 11.9 \\
Average & $6.7 \mathrm{~B}$ & $10.5 \mathrm{~A}$ & 14.8 & 14.0 & $7.0 \mathrm{~B}$ & $10.4 \mathrm{~A}$ & 9.5 & 11.6 \\
\hline
\end{tabular}

${ }^{*}$ NPK 500 - $500 \mathrm{~kg} \mathrm{ha-1}$ NPK 5-20-30; NPK1000 - $1000 \mathrm{~kg} \mathrm{ha}^{-1}$ NPK 5-20-30; ${ }^{* *}$ Factor level means accompanied by different letters are significantly different, with error $p \leq 0.05$ according to Tukey's HSD test. Small letters refer to fertilization treatments. Capital letters refer to average values of harvested and stored beetroot

Tab. 4. Nitrogen content (in \% N, in dry weight) in harvested and stored beetroot according to different fertilization treatments

\begin{tabular}{ccccccccc}
\hline & \multicolumn{9}{c}{$\%$ N, in Dry Weight } \\
\cline { 2 - 9 } & \multicolumn{2}{c}{2003} & \multicolumn{2}{c}{2004} & \multicolumn{2}{c}{2005} & \multicolumn{3}{c}{ Average } \\
\hline Treatment & Harvested & Stored & Harvested & Stored & Harvested & Stored & Harvested & Stored \\
\hline Control & 3.24 & 2.56 & 1.44 & 1.69 & $3.10 \mathrm{ab}$ & 2.21 & 2.59 & 2.15 \\
Manure & 3.42 & 2.56 & 1.46 & 1.70 & $3.17 \mathrm{ab}$ & 2.15 & 2.68 & 2.14 \\
NPK500* & 3.18 & 2.75 & 1.49 & 1.83 & $3.02 \mathrm{~b}$ & 2.32 & 2.56 & 2.30 \\
NPK1000* & 3.26 & 2.77 & 1.55 & 1.68 & $3.34 \mathrm{a}$ & 2.18 & 2.72 & 2.21 \\
Average & $3.28 \mathrm{~A}^{* *}$ & $2.66 \mathrm{~B}$ & 1.48 & 1.73 & 3.16 & 2.21 & 2.64 & 2.20 \\
\hline
\end{tabular}

${ }^{*}$ NPK 500 - $500 \mathrm{~kg} \mathrm{ha}^{-1}$ NPK 5-20-30; NPK1000 - $1000 \mathrm{~kg} \mathrm{ha}^{-1}$ NPK 5-20-30; **Factor level means accompanied by different letters are significantly different, with error $p \leq 0.05$ according to Tukey's HSD test. Small letters refer to fertilization treatments. Capital letters refer to average values of harvested and stored beetroot

Tab. 5. Nitrogen content (in $\mathrm{g} \mathrm{N} \mathrm{kg}^{-1}$, in fresh weight) in harvested and stored beetroot according to different fertilization treatments

\begin{tabular}{ccccccccc}
\hline & \multicolumn{9}{c}{$\mathrm{g} \mathrm{N} \mathrm{kg}^{-1}$, in fresh weight } \\
\cline { 2 - 9 } & \multicolumn{2}{c}{2003} & \multicolumn{2}{c}{2004} & \multicolumn{2}{c}{2005} & \multicolumn{2}{c}{ Average } \\
\hline Treatment & Harvested & Stored & Harvested & Stored & Harvested & Stored & Harvested & Stored \\
\hline Control & 2.31 & 2.60 & 2.12 & 2.45 & 2.26 & 2.39 & 2.23 & 2.48 \\
Manure & 2.11 & 2.88 & 2.03 & 2.30 & 1.99 & 2.13 & 2.04 & 2.44 \\
NPK500* & 2.14 & 3.00 & 2.23 & 2.34 & 2.12 & 2.28 & 2.16 & 2.54 \\
NPK1000* & 2.26 & 2.70 & 2.41 & 2.54 & 2.43 & 2.35 & 2.37 & 2.53 \\
Average & $2.20 \mathrm{~B}$ & $2.80 \mathrm{~A}$ & 2.20 & 2.41 & 2.20 & 2.29 & 2.20 & 2.50 \\
\hline
\end{tabular}

${ }^{*}$ NPK500 - $500 \mathrm{~kg} \mathrm{ha}^{-1}$ NPK 5-20-30; NPK1000 - $1000 \mathrm{~kg} \mathrm{ha}^{-1}$ NPK 5-20-30; **Factor level means accompanied by different letters are significantly different, with error $p \leq 0.05$ according to Tukey's HSD test. Small letters refer to fertilization treatments. Capital letters refer to average values of harvested and stored beetroot

ties of active substances (mineral elements) which are essential for the synthesis of organic compounds.

In 2004 and 2005, the highest contents of nitrogen and crude proteins (Tab. 4, 5 and 6) were determined in harvested beetroot in the treatment with $1000 \mathrm{~kg} \mathrm{ha}^{-1}$ NPK 5-20-30 (2.41 and $2.43 \mathrm{~g} \mathrm{~N} \mathrm{~kg}^{-1}$ in fresh weight and 15.07 and $15.21 \mathrm{~g}$ crude proteins $\mathrm{kg}^{-1}$ in fresh weight, respectively), which is in agreement with literature data (Lešić et al., 2002, Varo et al., 1980). Regardless of the fertilization treatment or trial year, average values of nitrogen and crude proteins were higher (in 2003 significantly) in stored than in harvested beetroot, by $14 \%$ on average.

In all three years of investigation the lowest crude protein content was determined in treatment with stable manure what confirmed that protien content production decreased by organic fertilization (Lairon, 2009; Mikkelsen and Hartz, 2008; Rembiałowska, 2007) as well as that plant accumulate more proteins with adequate nitrogen supply (Brandt and Molgaard, 2001).

These data are even more valuable given the fact that beetroot is the most consumed root vegetable, in comparison with other root vegetables, during the whole year as fresh, cooked or canned.

\section{Conclusions}

The highest content of crude proteins in fresh weight was obtained in 2004 and 2005 in fertilization treatment with $1000 \mathrm{~kg} \mathrm{ha}^{-1} \mathrm{NPK} 5-20-30$. In general, the crude protein content was higher in stored beetroot because of its decreasing water content ( $12 \%$ average loss) which, among other things, is one of the factors that can increase the nutritional quality of beetroot as a functional food. 
Tab. 6. Crude protein content (in $\mathrm{g}$ crude proteins $\mathrm{kg}^{-1}$, in fresh weight) in harvested and stored beetroot according to different fertilization treatments

\begin{tabular}{ccccccccc}
\hline & \multicolumn{9}{c}{ g crude proteins kg-1, in fresh weight } \\
\cline { 2 - 9 } & \multicolumn{2}{c}{2003} & \multicolumn{2}{c}{2004} & \multicolumn{2}{c}{2005} & \multicolumn{2}{c}{ Average } \\
\hline Treatment & Harvested & Stored & Harvested & Stored & Harvested & Stored & Harvested & Stored \\
\hline Control & 14.43 & 16.23 & 13.22 & 15.29 & 14.15 & 14.92 & 13.94 & 15.48 \\
Manure & 13.19 & 18.01 & 12.66 & 14.38 & 12.45 & 13.34 & 12.77 & 15.24 \\
NPK500* & 13.37 & 18.75 & 13.96 & 14.61 & 13.25 & 14.27 & 13.53 & 15.88 \\
NPK1000* & 14.13 & 16.90 & 15.07 & 15.89 & 15.21 & 14.68 & 14.80 & 15.82 \\
Average & $13.78 \mathrm{~B}^{* *}$ & $17.47 \mathrm{~A}$ & 13.73 & 15.04 & 13.76 & 14.30 & 13.76 & 15.61 \\
\hline
\end{tabular}

${ }^{*}$ NPK500 - $500 \mathrm{~kg} \mathrm{ha}^{-1}$ NPK 5-20-30; NPK1000 - $1000 \mathrm{~kg} \mathrm{ha}^{-1}$ NPK 5-20-30; ${ }^{* *}$ Factor level means accompanied by different letters are significantly different, with error $p \leq 0.05$ according to Tukey's HSD test. Small letters refer to fertilization treatments. Capital letters refer to average values of harvested and stored beetroot

\section{References}

AOAC (1995). Official method of analysis of AOAC International. $16^{\text {th }}$ Edition, Vol. I, Arlington, USA.

Bergmann W (1992). Nutritional disorders of plants. Gustav Fischer Verlag Jena, Stuttgart, New York.

Brandt K, Molgaard JP (2001). Organic agriculture: does it enhance or reduce the nutritional value of plant foods? J Sci Food Agric 81:924-931.

Ekholm P, Reinivuo H, Mattila P, Pakkala H, Koponen J, Happonen A, Hellström J, Ovaskainen MJ (2007). Changes in the mineral and trace element contents of cereals, fruits and vegetables in Finland. J Food Composit Analysis 20:487-495.

Feller C, Fink M (2004). Nitrate Content, Soluble Solids Content, and Yield of Table Beet as Affected by Cultivar, Sowing Date and Nitrogen Supply. HortSci 39(6):12551259.

Gopalan C, Tamber B (2003). Food-Based Approaches to Prevent and Control Micronutrient Malnutrition: Scientific Evidence and Policy Implications. World Rev Nutr Diet 91:76-131.

Grbeša D (2004). Evaluation methods and tables of chemical composition of the nutritional value of forage. Croatian Society of Agronomists, Zagreb.

Hallmann E, Rembiałkowska E (2012). Characterisation of antioxidant compounds in sweet bell pepper (Capsicum annuum L.) under organic and conventional growing systems. J Sci Food Agri, DOI 10.1002/jsfa.5624.

Herak Ćustić M, Horvatić M, Pecina M (2009). Nitrogen Fertilization Influences Protein Nutritional Quality in Red Head Chicory. J Plant Nutr 32(4):598-609.

Horvat T, Svečnjak Z, Karažija T, Gršić K (2011). Effect of foliar fertilizers on the intensity of photosynthesis and chlorophyll content index in potato leaf. Proc of the $10^{\text {th }}$ Alps-Adria Sci Workshop, Növénytermelés//Crop Production 60:93-96.

Lairon D (2009). Nutritional quality and safety of organic food. Agron Sustain Dev DOI: 10.1051/agro/2009019.

Lazarević B, Rubinić V, Bensa A (2011). Leaf relative chlorophyll content and plant sap nitrate-nitrogen concentration as indicators for predicting nitrogen status in maize (Zea mays L.). Proc of the $10^{\text {th }}$ Alps-Adria Sci Workshop, Növénytermelés//Crop Production 60:101-104.

Lešić R, Borošić J, Buturac I, Ćustić M, Poljak M, Romić D (2002). Vegetable production, Zrinski, Čakovec, 584-594 p.

Lisiewska Z, Kmiecik W, Gebczynnski P (2006). Effects on mineral content of different methods of preparing frozen root vegetables. Food Sci TechnolInternat 12:497-503.

Mikkelsen R, Hartz TK (2008). Nitrogen Sources for Organic Crop Production. Better Crops 92(4)16-19.

Petek M, Herak Ćustić M, Čoga L, Toth N, Pecina M (2008). Phosphorus content in soil and in fresh and cooked red beet in dependence on different fertilization. Cereal Res Commun 36(Suppl 1:435-438.

Rembiałkowska E (2007). Quality of plant products from organic agriculture. J Sci Food Agric 87:2757-2762.

Sorensen JN (1999). Nitrogen effects on vegetable crop production and chemical composition. Proc of the International Workshop on Ecological Aspects of Vegetable Fertilisation in Integrated Crop Production in the Field 506:41-49.

Vajić B (1964). Food, determination of the main ingredients. University of Zagreb, Zagreb.

Varo P, Lähelmä O, Nuurtamo M, Saari E, Koivistoinen (1980). Mineral element composition of finnish foods. Acta Agric Scand 22:89-113.

Veldkamp T, Van Krimpen MM, Jansman AJM (2008). Animal Sciences Group. Effect of vegetable diets versus diets with processed animal proteins on performance and health status of laying hens, Rapport 165.

Wang ZH, Li SX (2003). Effects of $\mathrm{N}$ forms and rates on vegetable growth and nitrate accumulation. Pedosphere 13(4):309-316.

Wang ZH, Li SX, Malhi S (2008). Effects of fertilization and other agronomic measures on nutritional quality of crops. J Sci Food Agric 88(1):7-23.

Wold AB, Wicklund T, Haffner K (2006). Antioxidant activity in commonly grown and consumed vegetables: a screening survey. J Appl Bot Food Quality 80:111-115.

Wybenga JM, Lehr JJ (1958). Exploratory pot experiments on sensitiveness of different crops to sodium. In: Red E (ed.). Table Beet. Plant and Soil IX, No. 4:385-394. 